\title{
Outros OlHares SOBRE a INClusão Escolar ${ }^{1}$
}

CALDERÓN ALMENDROS, Ignácio. Educación y esperanza en las fronteras de la discapacidad: estudio de caso único sobre la construcción creativa de la identidad. Madrid: CERMI/ Ediciones Cinca S.A., 2014.

O livro Educación y esperanza em läs fronteras de la discapacidad: estudio de caso único sobre la construcción creativa de la identidad de Ignácio Calderón Almendros reconstrói o processo educativo de seu irmão mais novo, Rafael, diagnosticado clinicamente com trissomia e identificado socialmente como um "Síndrome de Down", até o momento em que chega à educação formal superior e se torna a primeira pessoa com tais características a se graduar em trompete e receber o título de graduado em música na Espanha. De forma densa teoricamente, coesa textualmente e profunda no que se refere à sua relaçáo afetiva com seu irmão, o autor elabora uma narrativa solidamente apoiada em material de pesquisa, decorrentes de horas de entrevistas com vários grupos focais sobre suas relaçóes com a deficiência. Das entrevistas com familiares e amigos, passando pela análise de documentos oficiais e informes clínicos, às enquetes com seus professores e com estudantes do curso de formaçáo de educadores, o autor analisa esse material diversificado à luz do qual reconstitui o percurso de Rafael, dando visibilidade a uma série de barreiras comuns enfrentadas por pessoas como seu irmão, assim como demarcando seus modos de ser, o apoio de seu entorno familiar e os devires.

O que se percebe na elaboração desse percurso é que sem o apoio familiar as barreiras para que Rafael se formasse em música seriam ainda maiores para que chegasse onde chegou. Além de sua inabalável força vital, testemunhada em muitas entrevistas, esse apoio foi determinante para Rafael do mesmo modo que o inverso também ocorreu, como sensivelmente descreve o autor. É como se uma fragilidade comum impelisse a Rafael e seus familiares a ganharem mais força nessa comunhão e na luta contra uma tendência em neutralizar os mais frágeis e os oprimidos, sombrear as vozes que perdem formalmente sua potência.

Os relatos dessa luta pelos direitos de Rafael por parte de seus familiares e amigos, professores e procuradores públicos são abundantes no livro. Foi por intermédio da rede entretecida ao seu redor e desses laços interpessoais táo caros que Rafael que propiciaram vencer o processo de escolarizaçáo, chegando ao campo musical e a algumas comunidades que o acolheram sem perguntarem se gaguejava ou náo, apenas ouvindo o que expressava pelo seu trompete. Não se pode ignorar, também, que, ao invés de somente encorajar, muitas vezes, as vozes

\footnotetext{
${ }^{1}$ http://dx.doi.org/10.1590/S1413-65382317000100012

${ }^{2}$ Docente do Programa de Pós-Graduação em Educação, Unesp, Campus de Marília. Marília, SP, Brasil. pedropagni@gmail.com
} 
familiares serão encorajadas pela embocadura e pelo som forte da trombeta de Rafael, criando um outro arranjo, que se apresenta no livro como outra identidade.

Rafael dessa forma se tornou anônimo, comum, para que daí o reconhecessem por suas qualidades e capacidades de músico, de sua arte - e não por sua deficiência -, isto é, como alguém que atua nesse campo como um a mais. No campo musical recebeu instruçóes e críticas como todos os músicos, onde também pode expor-se não pela língua, mas pela arte, pelo sopro e pela música, invocando uma outra forma de reconhecimento e de comunicação em que uma desigualdade prévia se esvai. Foi nesse ambiente que encontrou, além de acolhimento, relações de poder menos associadas à opressão e, quem sabe, um pouco mais de paz em relaçóes interpessoais que suscitassem menos sofrimento para ele e onde pudesse ser ouvido, sendo dessa forma incluído.

A leitura desse percurso reconstruído pelo livro faz nos indagarmos sobre os porquês de essa inclusão não se processar de forma análoga na escola, mesmo quando se pretenda inclusiva. Isso porque se percebe aí o quanto seria tratado como um a menos. Nessa denúncia desenhada se percebe claramente o quanto os dispositivos da escola ainda se prestam a selecionar, a classificar e a hierarquizar seus atores, sobretudo, os alunos, se apresentando como mecanismos, mais do que de poder, de dominação ou, para usar o próprio vocabulário empregado pelo autor ao se apropriar da obra de Paulo Freire, de opressão. Nota-se ainda as formas como Rafael lidou com os impasses na escola ao ponto de ser possível vislumbra: de um lado, uma estratégia comum as de que muitas pessoas que são colocadas à margem se utilizam e,de outro, o ato de conviver com os efeitos de sua própria deficiência, revelando todo um processo de superação das dificuldades e dos limites vivenciados singularmente pelos deficientes, assim como a dos demais, inclusive, daqueles que falam em inclusão, sem desejar ouvir seu clamor sobre como gostaria de ser tratado: como um a mais. É esse clamor que Rafael catalisa, encarnando um signo de esperança para uma comunidade constituída de pessoas como ele, como seus familiares e amigos, espalhados por um mundo do qual também foram excluídos, sentindo na pele a sua opressão, mobilizando-os para uma luta em prol da ampliação de seus direitos e para que sejam vistos como vidas que são dignas de serem vividas como quaisquer outras.

Nesse ponto parece residir o espírito militante do livro que, sem perder a sua densidade acadêmica, convida o seu leitor: primeiro, a enxergar esse modo de existência dito deficiente como tantos outros e, inclusive, como bastante familiar aos nossos; segundo, a se engajar numa luta, concernente não mais a pessoas como Rafael e aos seus familiares, mas a todas as outras que a vislumbram como comum às suas em prol de liberação; por fim, a engrossar o coro da resistência que produzem contra um mundo regido pelo imperativo da eficiência, abrindo brechas para essa comunidade que vem. O livro tem dessa forma uma importância ímpar, análoga ao protagonismo de Rafael, para oxigenar um campo de estudos e de trabalho em que muitos pesquisadores e professores abriram mão de talhar essas brechas, de enxergarem em percursos como o de pessoas com alguma deficiência a possibilidade da criação de modos de existência outros e de as ouvirem antes de lhes enquadrar ou de lhes incluir segundo os preceitos teóricos ou técnico-científicos.

Recebido em: 04/12/2016

Aprovado em: 15/03/2017 